\title{
Pollution patterns in the upper troposphere over Europe and Asia observed by CARIBIC
}

\author{
Angela K. Baker ${ }^{\text {a, }}{ }^{*}$, Sebastian Traud ${ }^{\text {b, } 1}$, Carl A.M. Brenninkmeijer ${ }^{\text {a }}$, Peter Hoor ${ }^{\text {b }}$, \\ Marco Neumaier ${ }^{\text {c }}$, David E. Oram ${ }^{\mathrm{d}}$, Armin Rauthe-Schöch ${ }^{\mathrm{a}}$, Detlev Sprung ${ }^{\mathrm{c}, 2}$, \\ Sebastian Schloegl ${ }^{b}$, Franz Slemr ${ }^{a}$, Peter F.J. van Velthoven ${ }^{\mathrm{e}}$, Heini Wernli ${ }^{\mathrm{f}}$, \\ Andreas Zahn ${ }^{\mathrm{c}}$, Helmut Ziereis ${ }^{\mathrm{g}}$ \\ ${ }^{a}$ Max Planck-Institute for Chemistry, Hahn-Meitner-Weg 1, 55128 Mainz, Germany \\ ${ }^{\mathrm{b}}$ Institute for Atmospheric Physics, Johannes Gutenberg-University Mainz, 55099 Mainz, Germany \\ ${ }^{\mathrm{c}}$ Karlsruhe Institute of Technology, P.O. Box 3640, 76021 Karlsruhe, Germany \\ ${ }^{\mathrm{d}}$ National Centre for Atmospheric Science, University of East Anglia, Norwich NR4 7TJ, UK \\ e Royal Netherlands Meteorological Institute (KNMI), PO Box 201, 3730 AE De Bilt, Netherlands \\ ${ }^{\mathrm{f}}$ Institute for Atmospheric and Climate Science, ETH Zurich, Universitätstraße 16, 8092 Zurich, Switzerland \\ ${ }^{\mathrm{g}}$ Deutsches Zentrum für Luft- und Raumfahrt (DLR), Oberfaffenhofen, Germany
}

\section{H I G H L I G H T S}

- 3 years of observations used to study trace gas composition in the European and Asian UT.

- Transport from North America contributed to elevated acetone and $\mathrm{NO}_{y}$ over Europe.

- Strong influence of biomass burning on the UT over Southeast Asia.

- Elevated alkanes over Central Asia traced to South Asia and Eastern Europe.

\section{A R T I C L E I N F O}

\section{Article history:}

Received 20 March 2014

Received in revised form

2 June 2014

Accepted 3 June 2014

Available online 12 June 2014

\section{Keywords:}

Asian pollution

Upper troposphere

Airborne measurements

Long-range transport

Convection

\begin{abstract}
A B S T R A C T
Between May 2005 and March 2008 the CARIBIC (Civil Aircraft for the Regular Investigation of the atmosphere Based on an Instrument Container) observatory was deployed to make atmospheric observations on 42 flights between Frankfurt, Germany and Manila, the Philippines. This nearly 3 year flight series provides information about atmospheric composition in the upper troposphere over Europe and Asia during all seasons and was used to investigate seasonal and regional differences in trace gas distributions and the influence of long range transport and local convection on composition. The flight route was separated into three different regions having characteristic differences in transport and composition; these were Europe and Western Asia $\left(5^{\circ} \mathrm{E}-60^{\circ} \mathrm{E}\right)$, Central Asia $\left(60^{\circ} \mathrm{E}-100^{\circ} \mathrm{E}\right)$ and Southeast Asia $\left(100^{\circ} \mathrm{E}\right.$ $-125^{\circ} \mathrm{E}$ ). The region over Europe and Western Asia was strongly influenced by air masses from North America, while the region over Southeast Asia was mostly influenced by local emissions, particularly from biomass/biofuel burning as indicated by high levels of acetonitrile and carbon monoxide. Air masses over Central Asia were found to be influenced by both recent convection from the Indian subcontinent and mid-range transport from Europe, Western Asia and the Middle East. Elevated levels of propane and other non-methane hydrocarbons, both with and without concomitant elevations in other trace gases (i.e. carbon monoxide, acetonitrile) was a persistent feature over Central Asia in all seasons except summer, and were particularly prominent in fall. Influences on composition over Central Asia were investigated in detail for a case study from a series of flights in October 2006, where elevated levels of pollutants were found to be the result of convective transport of both biomass/biofuel burning and urban emissions from South Asia and fossil fuel related emissions from Eastern Europe.
\end{abstract}

(c) 2014 Elsevier Ltd. All rights reserved.

\footnotetext{
* Corresponding author.

E-mail address: angela.baker@mpic.de (A.K. Baker).

1 Now at: University of Tartu, Ulikooli 18, Tartu 51007, Estonia and Tartu Observatory, Toravere, Noo Parish 61602, Estonia.

2 Now at: Fraunhofer IOSB (Institute of Optronics, System Technologies and Image Exploitation), Gutleuthaustr. 1, 76275 Ettlingen, Germany. 


\section{Introduction}

Unlike Europe and North America, where emissions of pollutants have been stable or declining since the 1980s, pollutant emissions in Asia have risen strongly in recent decades as a result of rapid industrialization and economic development (Kurokawa et al., 2013; Ohara et al., 2007; Streets et al., 2003; Zhang et al., 2009). This has resulted in a number of large-scale studies of Asian pollution and emissions, with the majority focused on Southeast Asia, specifically China, and examining primarily air masses exported east containing Asian emissions (e.g. Hoell et al., 1996, 1997; Jacob et al., 2003; Singh et al., 2009). Despite the growing body of information on Asian emissions, there remains only a modest amount of data from observations over the continent, especially for regions outside of Eastern Asia. Even less data is available in the upper troposphere (UT) and most information is derived from satellite observations, with in situ data for some compounds available from a small number of MOZAIC aircraft flights (Heald et al., 2003; Nara et al., 2011; Nedelec et al., 2005; Tanimoto et al., 2008; Turquety et al., 2008).

Convective processes over Asia frequently transport boundary layer air into the UT where long range transport associated with movement in the jet stream rapidly redistributes Asian emissions globally within timescales of days to weeks (Liu et al., 2003; Turquety et al., 2008). Maximum convective activity occurs during summer, when the Asian summer monsoon dictates tropospheric circulation over South Asia (Qian and Lee, 2000). During this period frequent and persistent deep convection over the continent efficiently lofts polluted air masses from the boundary layer to the UT on a large scale, with uplifted pollutants being transported to the west where they contribute to elevated levels of tropospheric ozone over the Mediterranean (Baker et al., 2011; Lelieveld et al., 2002; Park et al., 2009; Randel et al., 2010; Scheeren et al., 2003; Schuck et al., 2010). In winter, convective activity is at a minimum and uplifting of boundary layer air is further suppressed by the Siberian High (Liu et al., 2003). Warm conveyor belts (WCBs) act to lift air from the Asian boundary layer into the free troposphere where it is then transported across the Pacific, with maximum activity in winter and spring (Cooper et al., 2004; Eckhardt et al., 2004). Similarly, WCBs also bring air from North America to the European UT, with maximum activity in winter (Auvray and Bey, 2005; Eckhardt et al., 2004).

Here we present trace gas data over Europe and Asia from CARIBIC (Civil Aircraft for the Regular Investigation of the atmosphere Based on an Instrument Container) observations made during flights from Frankfurt, Germany to Manila, the Philippines. During these flights, which took place near monthly for a period of almost three years, regionally dependent trends and patterns were systematically observed. We focus on characterizing these patterns and examining the influence of mid- to long range transport of pollutants versus convectively injected local emissions in the UT over Europe and Asia. We also present a case study of one flight having exceptionally high levels of pollution attributable to emissions from both South Asia and Eastern Europe which is characteristic of conditions causing elevated levels of alkanes in the UT over Central Asia.

\section{Materials and methods}

CARIBIC is a long-term atmospheric monitoring program wherein a 1.6 ton instrument container is deployed monthly aboard a Lufthansa Airlines Airbus 340-600 passenger jet to make measurements during long-distance flights between Frankfurt, Germany and various destinations around the globe (Brenninkmeijer et al., 2007). The project has been operational since 2005 and deployments are ongoing as of this writing. The CARIBIC scientific payload consists of 15 measurement systems, is fully automated, and carries out in-situ trace gas and aerosol measurements, as well as remote sensing by DOAS and the collection of aerosol and whole air samples. Discussed in detail here are carbon monoxide (CO), nitrogen oxides $\left(\mathrm{NO}_{y}\right)$, acetone $\left(\mathrm{C}_{3} \mathrm{H}_{6} \mathrm{O}\right)$, acetonitrile $\left(\mathrm{CH}_{3} \mathrm{CN}\right)$ and measurements of non-methane hydrocarbons (NMHCs) from the whole air samples, brief descriptions of which are provided below.

CO is measured with a commercial AeroLaser AL 5002 resonance fluorescence UV instrument modified for use in the CARIBIC container (Scharffe et al., 2012). Alterations were necessary to optimize instrument reliability and allow for automated operation over an entire flight sequence, which can last several days. The instrument has a precision of $1-2 \mathrm{ppbv}$ at an integration time of $1 \mathrm{~s}$ and performs an in-flight calibration every $25 \mathrm{~min}$.

Total nitrogen oxides $\left(\mathrm{NO}_{y}\right)$ are measured using a two-channel nitrogen oxide detector (Eco Physics AG, Rheinfelden, Switzerland). The detector was adapted for use in the UT and lower stratosphere (LS) and has been deployed on the DLR Falcon research aircraft (Ziereis et al., 2000). A conventional chemiluminescence detection is used with $\mathrm{NO}_{y}$ being detected after catalytic conversion to $\mathrm{NO}$ at a resolution of $1 \mathrm{~Hz}$ with an overall uncertainty of about $8 \%$ at a concentration of $0.5 \mathrm{ppbv}$ (Brough et al., 2003; Ziereis et al., 2000).

Acetone and acetonitrile are measured using proton transfer reaction mass spectrometry (PTRMS). The CARIBIC PTRMS is a commercially available instrument (Ionicon, Innsbruck, Austria) which has been extensively modified for use in the UT/LS (Sprung and Zahn, 2010). The instrument scans for 7 compounds over a $30 \mathrm{~s}$ period, and acetone and acetonitrile are scanned for $5 \mathrm{~s}$ out of each 30 s scan. Uncertainty is $15 \%$ for tropospheric measurements.

Whole air samples were collected in two sampling units, each of which houses 14 glass sampling flasks of 2.7 l volume, pressurized to 4.5 bar during collection (Schuck et al., 2009). Samples are collected at pre-determined, evenly spaced intervals of $\sim 35 \mathrm{~min}$ $(\sim 480 \mathrm{~km})$ with filling times between $0.5 \mathrm{~min}$ and $1.5 \mathrm{~min}$ $(\sim 7-22 \mathrm{~km})$. NMHCs were analyzed post-flight at the Max Planck Institute for Chemistry (MPIC) in Mainz using gas chromatography (GC) with flame ionization detection (Baker et al., 2010). Also measured from the air samples are greenhouse gases (carbon dioxide, methane, nitrous oxide and sulfur hexafluoride), which are also analyzed at the MPIC (Schuck et al., 2009), and halocarbons, which are measured at the University of East Anglia in Norwich, UK (Krol et al., 2003).

For each flight meteorological analyses and backwards trajectory calculations are made based on ECMWF re-analyzed data determined along the flight track (van Velthoven, 2014). Wind fields are available at a $1^{\circ} \times 1^{\circ}$ resolution every $6 \mathrm{~h}$, and meteorological data are interpolated from the ECMWF data at $1 \mathrm{~min}$ time steps. The KNMI TRAJKS model is used to calculate 5 day back trajectories along the flight track at 3 min intervals (Scheele et al., 1996). Additionally, for each air sample 8-day backwards trajectories are calculated for the sampling interval. For this study additional trajectory analyses were made using the LAGRANTO tool, which also utilizes ECMWF data (Wernli and Davies, 1997).

CARIBIC flights operate at altitudes between 8.5 and $12.5 \mathrm{~km}$, placing the aircraft in the middle free troposphere when in the tropics and subtropics, and in the UT/LS at higher latitudes. For the work presented here only tropospheric data have been considered, and data having stratospheric influence were excluded. Stratospheric influence was identified if any of the following three criteria were met: potential vorticity greater than 2 PVU, ozone greater than 150 ppbv or an ozone concentration greater than the 
concentration at the chemical tropopause, as described in (Zahn et al., 2002; Zahn et al., 2004).

Between May 2005 and March 2008 the CARIBIC observatory was deployed on 42 flights originating in Frankfurt, Germany (FRA) and going to Manila, the Philippines (MNL) with a stopover in Guangzhou, China (CAN) (Fig. 1). A complete listing of flights and data availability is given in Table 1. Flights took place at approximately the same time of day for each month in which the container was deployed, with take-off in Frankfurt between 21:00 and 23:00 UTC on the first day and return to Frankfurt between 3:00 and 5:00 UTC on the third day. Of these approximately $32 \mathrm{~h}$, about 24 were flight hours, $21 \mathrm{~h}$ on the FRA-CAN route and $3 \mathrm{~h}$ on the CAN-MNL route. In the following we examine these flights as a series in order to gain a systematic understanding of the general composition of trace gases in the UT over Europe and Asia.

\section{Results and discussion}

The bulk of this analysis focuses on six trace gas species which serve as tracers of air mass origin, namely $\mathrm{CO}, \mathrm{NO}_{y}$, acetonitrile, acetone, benzene and propane. $\mathrm{CO}$ is the product of incomplete combustion and can be broadly applied as a tracer for air masses of urban/anthropogenic origin or containing emissions from biomass and/or biofuel burning (Bergamaschi et al., 2000; Novelli, 1999; Novelli et al., 1992). $\mathrm{NO}_{y}$ (total reactive nitrogen) also serves as a tracer of anthropogenic and biomass burning emissions, as well as lightning emissions, and, in certain cases can also be an indicator of photochemical processing, as it includes not only $\mathrm{NO}_{x}\left(\mathrm{NO}+\mathrm{NO}_{2}\right)$ but the products of the atmospheric reactions of $\mathrm{NO}_{x}$ with $\mathrm{OH}$ $\left(\mathrm{HNO}_{3}\right)$ and VOCs (peroxyacetylnitrates, alkyl nitrates) (Logan, 1983). Acetone $\left(\mathrm{C}_{3} \mathrm{H}_{6} \mathrm{O}\right)$ is the product of both primary emissions and secondary photochemical production, however, it has biogenic sources in addition to anthropogenic and biomass burning emissions and is the product of reactions of VOCs emitted by both the biosphere (isoprene, monoterpenes) and anthropogenic fossil fuel use $\left(C_{3}-C_{5}\right.$ alkanes) (Jacob et al., 2002; Singh et al., 1995). Acetonitrile $\left(\mathrm{CH}_{3} \mathrm{CN}\right)$ is almost exclusively the product of biomass and biofuel burning and serves as a unique tracer for these sources (Andreae and Merlet, 2001; de Gouw et al., 2003). Like acetonitrile, benzene $\left(\mathrm{C}_{6} \mathrm{H}_{6}\right)$ also has a large source from biomass and biofuel burning, but is also emitted by other (anthropogenic) combustion sources and the evaporation of solvents and fuels of which it is a component, although these sources are decreasing as benzene is removed from fuels due to its status as a carcinogen (Lewis et al., 2013). Propane $\left(\mathrm{C}_{3} \mathrm{H}_{8}\right)$ is emitted predominantly by anthropogenic sources, with only a small biomass burning component, and

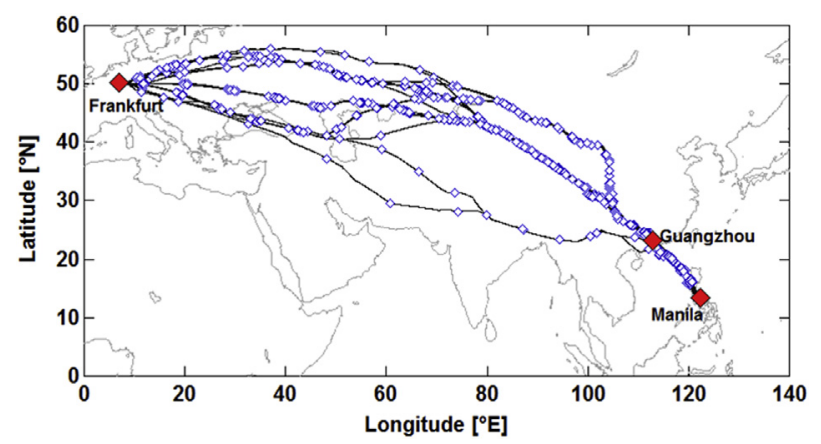

Fig. 1. Flight tracks between Frankfurt, Germany and Manila, the Philippines. Solid black lines show the flight path and open blue diamonds denote sample collection points. (For interpretation of the references to colour in this figure legend, the reader is referred to the web version of this article.)
Table 1

Dates and data availability for FRA-CAN-MNL flights.

\begin{tabular}{lllllll}
\hline Flight series & Flight dates & $\mathrm{CO}^{\mathrm{a}}$ & $\mathrm{NO}_{y}{ }^{\mathrm{a}}$ & $\mathrm{CH}_{3} \mathrm{CN}^{\mathrm{a}}$ & Acetone $^{\mathrm{a}}$ & $\mathrm{NMHCs}^{\mathrm{b}}$ \\
\hline 1 & 19-21 May 2005 & 4 & 4 & 4 & 4 & 26 \\
2 & 14-16 Nov 2005 & 4 & 4 & 0 & 0 & 26 \\
3 & 27-29 April 2006 & 4 & 4 & 4 & 4 & 28 \\
4 & 29-31 May 2006 & 4 & 4 & 4 & 4 & 14 \\
5 & 5-7 July 2006 & 4 & 4 & 2 & 4 & 28 \\
6 & 31 July-2 Aug 2006 & 4 & 2 & 4 & 4 & 0 \\
7 & 7-9 Sept 2006 & 4 & 4 & 4 & 4 & 0 \\
8 & 19-21 Oct 2006 & 4 & 4 & 4 & 4 & 28 \\
9 & 14-16 Nov 2006 & 4 & 4 & 4 & 4 & 28 \\
10 & 13-15 Dec 2006 & 4 & 4 & 4 & 4 & 28 \\
11 & 5-7 Feb 2007 & 4 & 4 & 4 & 4 & 28 \\
12 & 6-8 Mar 2007 & 4 & 4 & 4 & 4 & 28 \\
13 & 18-20 April 2007 & 4 & 2 & 4 & 4 & 27 \\
14 & 22-24 May 2007 & 4 & 4 & 4 & 4 & 28 \\
15 & 21-23 June 2007 & 4 & 4 & 4 & 4 & 25 \\
16 & 17-19 July 2007 & 4 & 4 & 4 & 4 & 0 \\
17 & 14-16 Aug 2007 & 4 & 4 & 4 & 4 & 28 \\
18 & 24-26 Oct 2007 & 4 & 4 & 4 & 4 & 28 \\
19 & 13-15 Nov 2007 & 4 & 4 & 4 & 4 & 28 \\
20 & 25-27 Feb 2008 & 4 & 0 & 4 & 4 & 27 \\
21 & 26-28 Mar 2008 & 4 & 4 & 4 & 4 & 28 \\
\hline
\end{tabular}

a Number of flights in series for which data is available (out of 4 individual flights). b Number of whole air samples with data (out of 28 possible). Includes samples with stratospheric influence.

serves as a tracer for anthropogenic fossil fuel use, primarily liquefied petroleum gas (LPG) and natural gas (D R Blake and Rowland, 1995).

Based on a combination of chemical and meteorological data, as well as the structure of the flight routes, the data has been divided into three regions: Europe and Western Asia $\left(5^{\circ} \mathrm{E}-60^{\circ} \mathrm{E}\right)$, Central Asia $\left(60^{\circ} \mathrm{E}-100^{\circ} \mathrm{E}\right)$ and Southeast Asia $\left(100^{\circ} \mathrm{E}-125^{\circ} \mathrm{E}\right)$. Data over Europe/West Asia represent the portion of the flight when the aircraft was flying in a relatively broad corridor between about $40^{\circ} \mathrm{N}$ and $65^{\circ} \mathrm{N}$ latitude (Fig. 1). During these flight sections the aircraft frequently encountered air masses from further afield, having passed over North America and the North Atlantic, and occasionally from Europe and the Mediterranean (Fig. 2). The aircraft also spent substantial time in the tropopause region and lowermost stratosphere, creating a sparser tropospheric dataset, particularly for the coarser resolution WAS data. Central Asian data represent the section of the flight when the aircraft is moving from $\sim 45^{\circ} \mathrm{N}$ to $30^{\circ} \mathrm{N}$, generally within a much narrower corridor, and is almost exclusively over Western China. Encountered air masses had frequently passed over Europe/West Asia, the Arabian Peninsula or the Indian subcontinent, and occasionally over Africa, Eastern China and the Indochinese Peninsula. The portions of the flight route over Eastern China and the South China Sea are defined as Southeast Asia and are influenced primarily by air masses of local origin from China and the Indochinese Peninsula, and occasionally from Indonesia and the Philippines. Encounters with air having been in the lower troposphere ( $>650 \mathrm{hPa}$ ) within 8 days prior to sampling was not uncommon, occurring about one third of the time in the troposphere, irrespective of season.

\subsection{Spatial and temporal distributions of trace gases over Asia}

In order to examine the distributions of the different trace gases in the UT over Asia mean mixing ratios were determined for each of 24 longitude bins having widths of $5^{\circ}$ (Fig. 3a). Apparent in these distributions are elevated $\mathrm{CO}$, acetonitrile and benzene and low propane over Southeast Asia, and elevated $\mathrm{NO}_{y}$ and acetone over Europe/West Asia. Also visible are enhancements in benzene and propane over Central Asia without concomitant enhancements in 
CARIBIC2 WAS trajectories for the CAN/MNL flights in 2005-2008
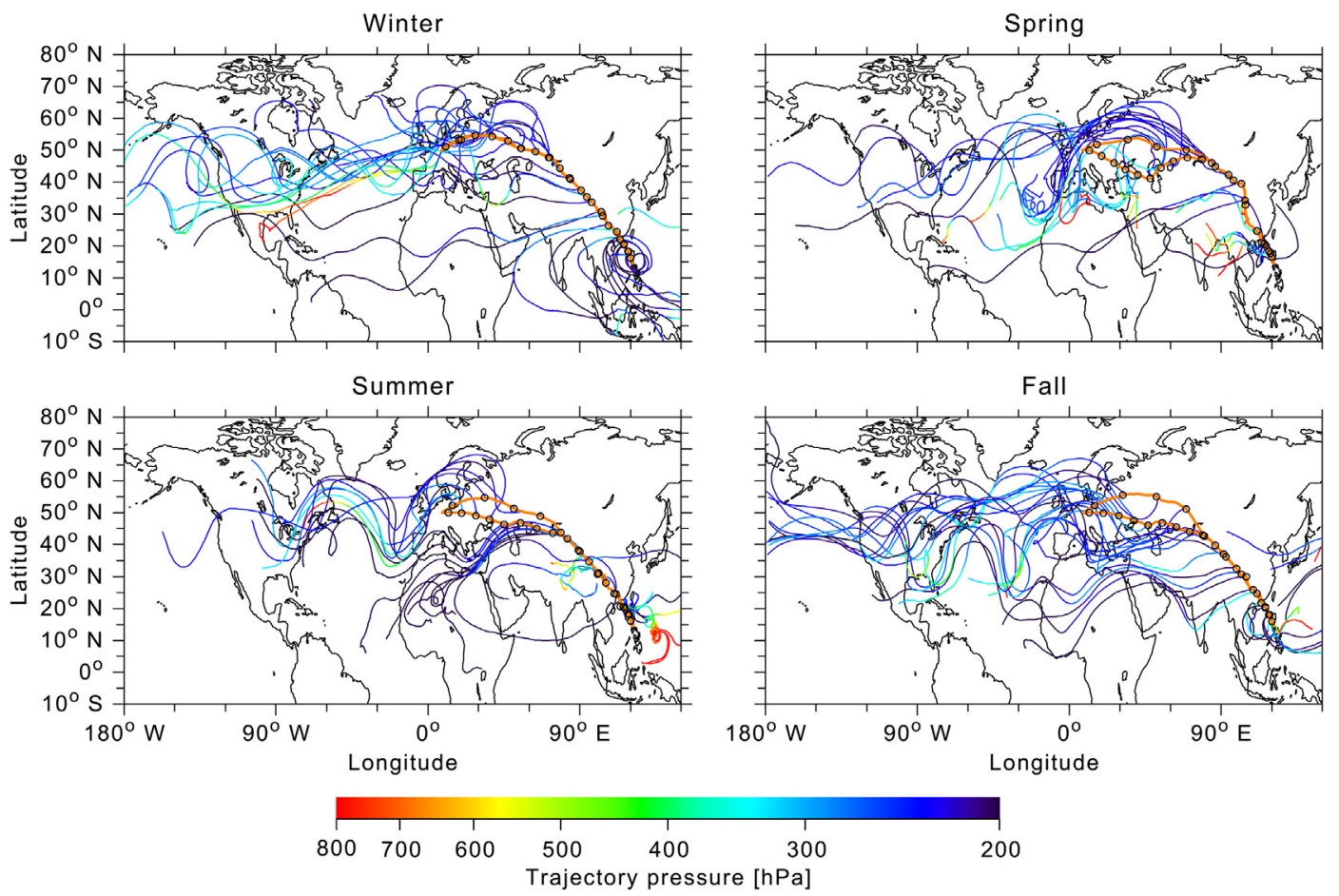

Fig. 2. Seasonally representative backward trajectories for whole air samples collected along the Frankfurt-Guangzhou-Manila route.

CO or acetonitrile. However, variability is large, attributable to these means being derived from all data, irrespective of season. As potentially large seasonal differences in mixing ratios are expected due to changes in emissions, loss processes and differing meteorology, seasonal means have also been calculated and the profiles examined (Fig. 3b). For this analysis three-month seasons were defined, with January through March representing winter, April through June representing spring, July through September representing summer and October through December representing fall. Average seasonal mixing ratios for each region are given in Table 2.

Seasonal profiles reveal patterns not always captured by the annual data (Fig. 3b). Clear in all seasons are the enhanced CO, acetonitrile and benzene and reduced propane over Southeast Asia mentioned above. Previous work looking in detail at this region showed that air masses were frequently influenced by both biomass burning and anthropogenic emissions from China and the Indochinese Peninsula, with a lesser influence from Indonesia, the Philippines, India and Northeast Asia (Lai et al., 2011; Lai et al., 2010). Also evident are decreasing levels of $\mathrm{NO}_{y}$ and acetone moving east during spring and summer, with no clear trend during fall and winter. Additionally, enhancements in $\mathrm{NO}_{y}$ and acetone over Europe/West Asia during spring and summer are much larger relative to fall and winter mixing ratios than over Central and Southeast Asia. This can be attributed in part to the latitudinal gradient which is also superimposed on the data, as the aircraft is not only flying east/west but also south/north (Fig. 1), and a larger summer to winter gradient would be expected further north, on the most western portion of the flight route. As these air masses tend to originate primarily over North America, elevated $\mathrm{NO}_{y}$ and acetone are likely a result of increased convection bringing emissions from North America and Europe to the UT, and is supported by previous finding of the strong influence of
North American and European emissions on UT composition over Asia during summer (Auvray and Bey, 2005). For acetone the spring and summer enhancements can be attributed to increased photochemical production, and the absence of concomitant increases in primary tracers is an indication that $\mathrm{NO}_{y}$ may be largely composed of non- $\mathrm{NO}_{x} \mathrm{NO}_{y}$ and/or is attributable to increased lightning production of $\mathrm{NO}_{x}$. Despite being a receptor region for WCB outflow from North America, with maximum activity expected in winter (Eckhardt et al., 2004), there is no obvious influence of WCB outflow on UT composition over Europe/West Asia during winter.

Also clear in the seasonal data is elevated propane over Central Asia in all seasons but summer, and these enhancements are occasionally accompanied by enhanced levels of other tracers. During fall elevated propane is accompanied by exceptionally high benzene and elevations in acetone, acetonitrile, and $\mathrm{NO}_{y}$ while $\mathrm{CO}$ is only moderately enhanced. Wintertime enhancements are accompanied only by enhanced benzene and slight enhancements in $\mathrm{CO}$, while springtime enhancements in propane do not appear to be accompanied by elevated levels in any of the other trace gases. Examination of backward trajectories show that air masses having high levels of all or most tracers frequently passed over the Indian subcontinent and could be traced back to low altitudes (using trajectories) and/or to convective systems (using satellite cloud imagery). These air masses frequently had trace gas relationships characteristic of biomass/biofuel burning and urban emissions. Conversely, air masses where propane (and other alkanes) was enhanced without concomitant enhancements in other tracers were usually traceable to Europe/West Asia and the Arabian Peninsula, and air mass composition was more characteristic of fossil fuel extraction and storage, particularly liquefied petroleum gas (LPG), which contains a large propane fraction. Although the average seasonal distributions show tendencies toward one air 

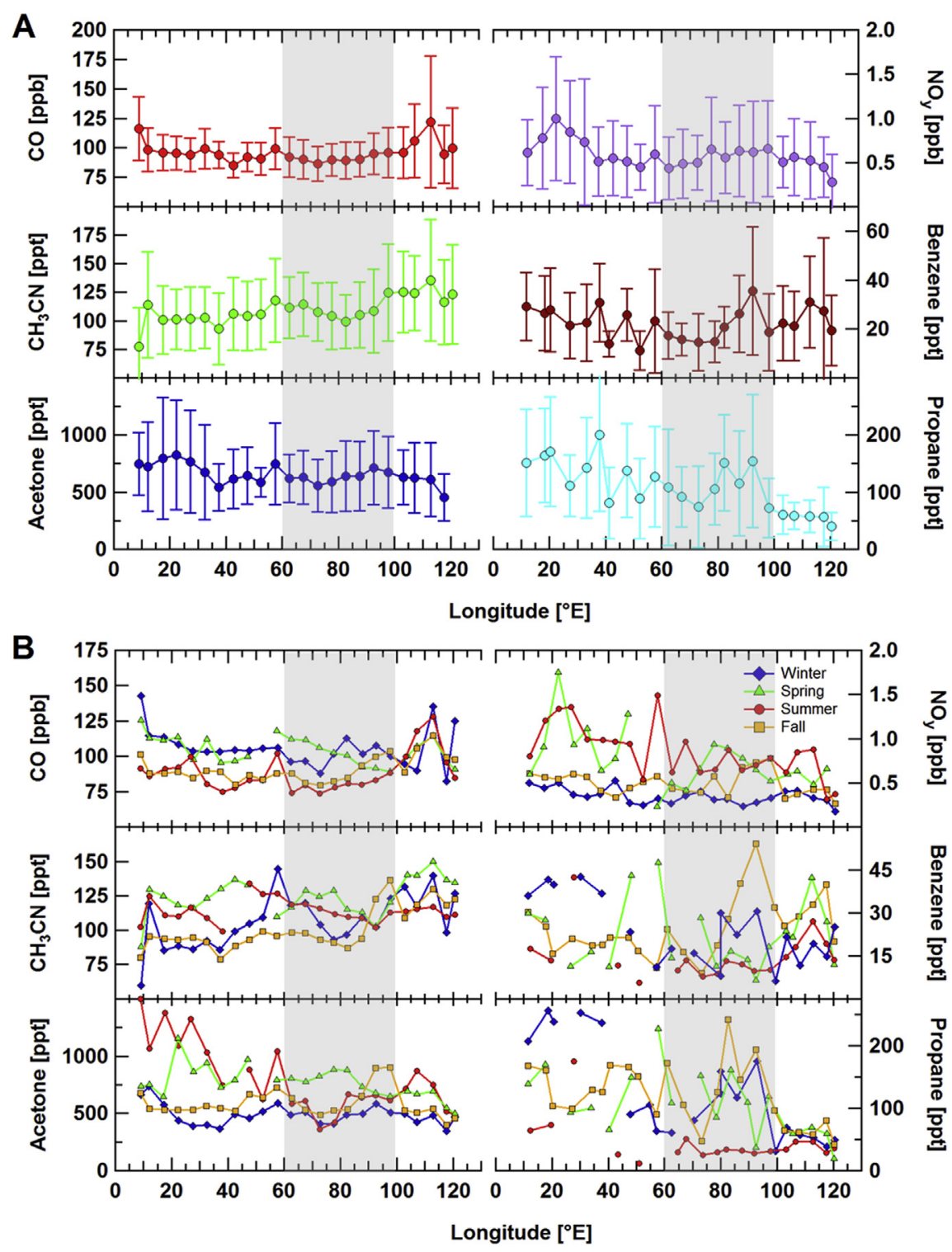

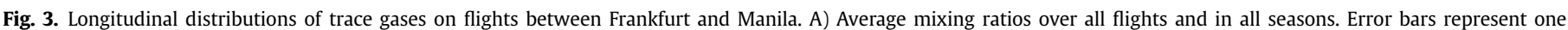

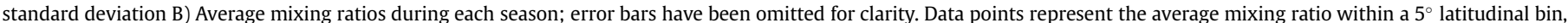
with bins beginning at $5^{\circ} \mathrm{E}$ and going until $125^{\circ} \mathrm{E}$. Gray shaded areas represent the Central Asian region $\left(60^{\circ} \mathrm{E}-100^{\circ} \mathrm{E}\right)$.

mass type or another, all types were encountered in each season (except summer); one flight series from October 2006 where these various air masses were all encountered is discussed in more detail in Section 3.3.
Given the importance of season visible in the longitudinal profiles, seasonal cycles for each of the six compounds for each of the three regions are shown in Fig. 4. Seasonal cycles were approximated by fitting to the equation

Table 2

Average mixing ratios of trace gases by region and season. Errors represent one standard deviation.

\begin{tabular}{|c|c|c|c|c|c|c|c|c|}
\hline Region & Season & $\mathrm{CO}(\mathrm{ppb})$ & $\mathrm{NO}_{y}(\mathrm{ppb})$ & $\mathrm{CH}_{3} \mathrm{CN}$ (ppt) & Acetone (ppt) & Ethane (ppt) & Propane (ppt) & Benzene (ppt) \\
\hline \multirow[t]{4}{*}{ Eastern Europe } & Winter & $110 \pm 16$ & $0.36 \pm 0.15$ & $103 \pm 38$ & $525 \pm 222$ & $920 \pm 243$ & $181 \pm 105$ & $33 \pm 15$ \\
\hline & Spring & $110 \pm 17$ & $0.91 \pm 0.70$ & $124 \pm 31$ & $823 \pm 406$ & $921 \pm 266$ & $125 \pm 66$ & $23 \pm 16$ \\
\hline & Summer & $90 \pm 15$ & $1.18 \pm 0.48$ & $117 \pm 37$ & $1153 \pm 524$ & $518 \pm 193$ & $63 \pm 52$ & $16 \pm 11$ \\
\hline & Fall & $88 \pm 11$ & $0.52 \pm 0.47$ & $93 \pm 27$ & $571 \pm 200$ & $695 \pm 165$ & $145 \pm 76$ & $22 \pm 10$ \\
\hline \multirow[t]{4}{*}{ Central Asia } & Winter & $102 \pm 11$ & $0.30 \pm 0.11$ & $109 \pm 31$ & $498 \pm 152$ & $843 \pm 209$ & $135 \pm 78$ & $23 \pm 16$ \\
\hline & Spring & $98 \pm 17$ & $0.69 \pm 0.42$ & $118 \pm 27$ & $762 \pm 294$ & $820 \pm 314$ & $117 \pm 65$ & $17 \pm 10$ \\
\hline & Summer & $82 \pm 14$ & $0.73 \pm 0.32$ & $111 \pm 20$ & $600 \pm 300$ & $427 \pm 71$ & $30 \pm 11$ & $10 \pm 4$ \\
\hline & Fall & $90 \pm 17$ & $0.56 \pm 0.64$ & $104 \pm 42$ & $666 \pm 302$ & $694 \pm 331$ & $128 \pm 98$ & $30 \pm 21$ \\
\hline \multirow[t]{4}{*}{ East Asia } & Winter & $103 \pm 55$ & $0.37 \pm 0.24$ & $121 \pm 49$ & $434 \pm 229$ & $539 \pm 141$ & $49 \pm 33$ & $18 \pm 11$ \\
\hline & Spring & $103 \pm 26$ & $0.62 \pm 0.37$ & $141 \pm 36$ & $645 \pm 241$ & $625 \pm 177$ & $60 \pm 30$ & $28 \pm 18$ \\
\hline & Summer & $109 \pm 40$ & $0.59 \pm 0.45$ & $113 \pm 26$ & $701 \pm 338$ & $391 \pm 108$ & $35 \pm 15$ & $19 \pm 12$ \\
\hline & Fall & $102 \pm 30$ & $0.37 \pm 0.25$ & $119 \pm 40$ & $485 \pm 195$ & $539 \pm 167$ & $67 \pm 53$ & $33 \pm 32$ \\
\hline
\end{tabular}



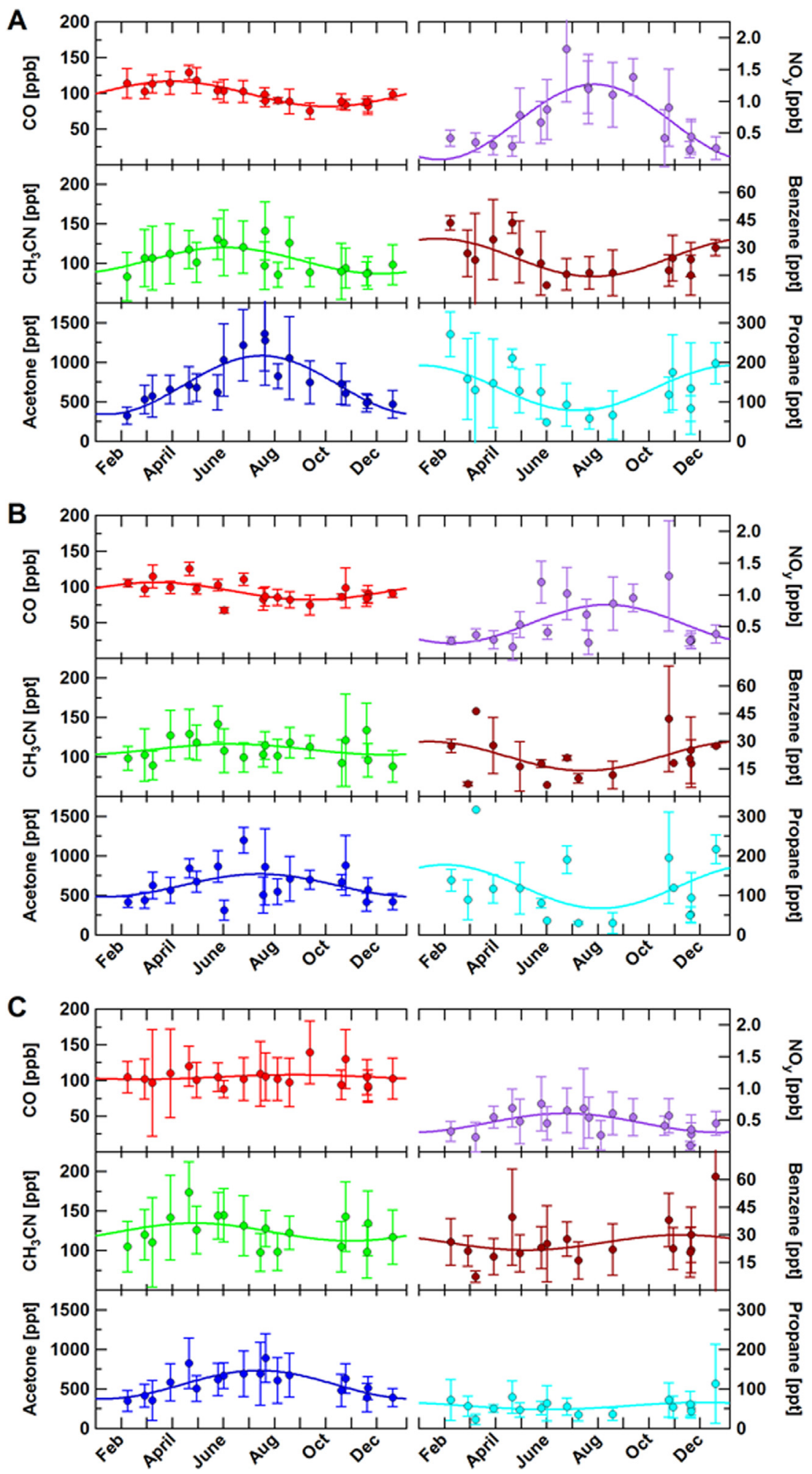

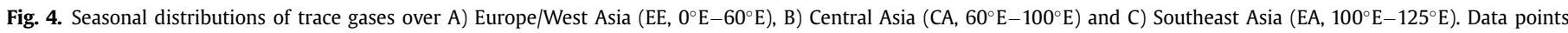

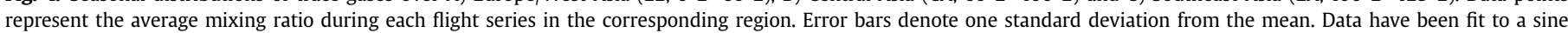
function to estimate the seasonal cycles (denoted by solid lines; see text).

$f(t)=A+B \cos \left[(t-C) \frac{2 \pi}{365}\right]$

where $A$ is the annual mean, $B$ is the amplitude of the seasonal cycle and $C$ is the day of year at the maximum mixing ratio. Fit parameters are given in Table 3 . In the absence of seasonally changing emissions the lowest mixing ratios of compounds having predominantly primary sources would be expected in summer and fall and the highest values would be expected in winter and spring. For compounds which are also (or exclusively) produced 
Table 3

Fit parameters for seasonal cycles of trace gases. Errors denote 95\% confidence interval for the fit.

\begin{tabular}{llccc}
\hline Compound & Region & \multicolumn{2}{c}{$\mathrm{A}$} & \multicolumn{2}{c}{$\mathrm{C}$} \\
\hline $\mathrm{CO}$ & Europe/West Asia & $99.0 \pm 2.9$ & $17.7 \pm 4.0$ & $90.1 \pm 13.7$ \\
& Central Asia & $93.8 \pm 5.5$ & $12.2 \pm 7.9$ & $71.1 \pm 36.6$ \\
& Southeast Asia & $104.6 \pm 6.3$ & $-3.2 \pm 9.3$ & $51.4 \pm 155$ \\
$\mathrm{CH}_{3} \mathrm{CN}$ & Europe/West Asia & $103.4 \pm 6.7$ & $16.6 \pm 9.4$ & $151.4 \pm 32.8$ \\
& Central Asia & $109.4 \pm 7.8$ & $6.8 \pm 11.0$ & $158.9 \pm 93.7$ \\
& Southeast Asia & $123.3 \pm 10.2$ & $11.2 \pm 13.8$ & $116.56 \pm 76.8$ \\
Acetone & Europe/West Asia & $710.0 \pm 76.6$ & $370.2 \pm 112$ & $194.6 \pm 16.2$ \\
& Central Asia & $624.3 \pm 102$ & $143.5 \pm 148$ & $192.5 \pm 55.6$ \\
& Southeast Asia & $551.8 \pm 51.8$ & $179.0 \pm 74.2$ & $191.4 \pm 23.2$ \\
$\mathrm{NO}_{y}$ & Europe/West Asia & $0.67 \pm 0.14$ & $0.59 \pm 0.21$ & $206.2 \pm 17.2$ \\
& Central Asia & $0.54 \pm 0.37$ & $0.30 \pm 0.27$ & $220.3 \pm 42.8$ \\
& Southeast Asia & $0.45 \pm 0.07$ & $0.15 \pm 0.10$ & $171.3 \pm 41.2$ \\
Benzene & Europe/West Asia & $24.5 \pm 4.0$ & $10.3 \pm 6.0$ & $46.5 \pm 30.2$ \\
& Central Asia & $21.8 \pm 5.9$ & $-7.9 \pm 8.9$ & $194.4 \pm 58.5$ \\
& Southeast Asia & $25.7 \pm 6.4$ & $-4.1 \pm 8.3$ & $125.9 \pm 140$ \\
Propane & Europe/West Asia & $129.9 \pm 24.0$ & $67.2 \pm 37.8$ & $36.2 \pm 36$ \\
& Central Asia & $121.9 \pm 42.0$ & $54.0 \pm 66$ & $30.3 \pm 56.8$ \\
& Southeast Asia & $56.5 \pm 10.9$ & $-8.8 \pm 14.7$ & $151.0 \pm 108$ \\
\hline
\end{tabular}

photochemically, summertime maxima would be expected, if production is sufficient to counterbalance losses. Deviations from the expected seasonal cycles could point to rapid transport to the UT via convection, or seasonally changing sources (either of the emissions themselves or of the source regions).

Seasonal cycles over Europe/West Asia have much larger amplitudes than over other regions, attributable to the larger seasonal variations in photochemistry at higher latitudes, with minor influence by varying transport regimes. $\mathrm{CO}$, benzene, propane and acetonitrile, follow the expected seasonal pattern for primary species, although there are a few enhanced mixing ratios of acetonitrile during summer, possibly related to transport of North American biomass burning emissions or convection of regional burning. Conversely, acetone and $\mathrm{NO}_{y}$ have summer time maxima. For acetone this is likely related to enhanced photochemical production and biogenic emissions, while for $\mathrm{NO}_{y}$ this could be related to both increased lightning activity and enhanced convection during summer.

Over Central and Southeast Asia, seasonal cycles are similar to those observed over Europe/West Asia, however, their amplitudes are dampened. Notable deviations are the lack of any significant seasonal pattern for $\mathrm{CO}$, benzene and propane over Southeast Asia. Levels of $\mathrm{CO}$ and benzene remain elevated and highly variable, while propane remains very low. This is the result of frequent input from the boundary layer of air masses from a wide variety of sources and source regions, as discussed in previous work (Lai et al., 2011). Also of note are some instances of unexpectedly low levels of $\mathrm{CO}, \mathrm{NO}_{y}$ and acetone over Central Asia during summer. Instances of low $\mathrm{CO}, \mathrm{NO}_{y}$ and acetone were from measurements in June-August 2006 and can be traced back to encounter of air which had been transported at altitude for extended periods of time in the UT anticyclone formed during the Asian summer monsoon. During summer 2007 the aircraft flew at a more northerly route when over Central Asia (see Fig. 1) therefore bypassing the monsoon anticyclone and instead regularly encountered air having recent contact with the Asian boundary layer, thus resulting in higher levels of observed trace gases.

\subsection{Trace gas relationships and sources}

To further our identification of the varied sources at play in the different regions and during different seasons we investigated the relationships between several tracers and $\mathrm{CO}$. The use of $\mathrm{CO}$ as the reference tracer stems from it being a ubiquitous pollutant emitted by combustion sources, which serves as an excellent tracer of boundary layer air. Additionally, there exist in the literature a number of studies using $\mathrm{CO}$ as a reference tracer and citing its relationship to other species as a means to estimate emission ratios and identify sources (Andreae and Merlet, 2001; Blake et al., 2003; Mauzerall et al., 1998; Woo et al., 2003). Plots of $\mathrm{NO}_{y}$, acetone and acetonitrile versus $\mathrm{CO}$ are shown in Fig. 5 and the slopes of the
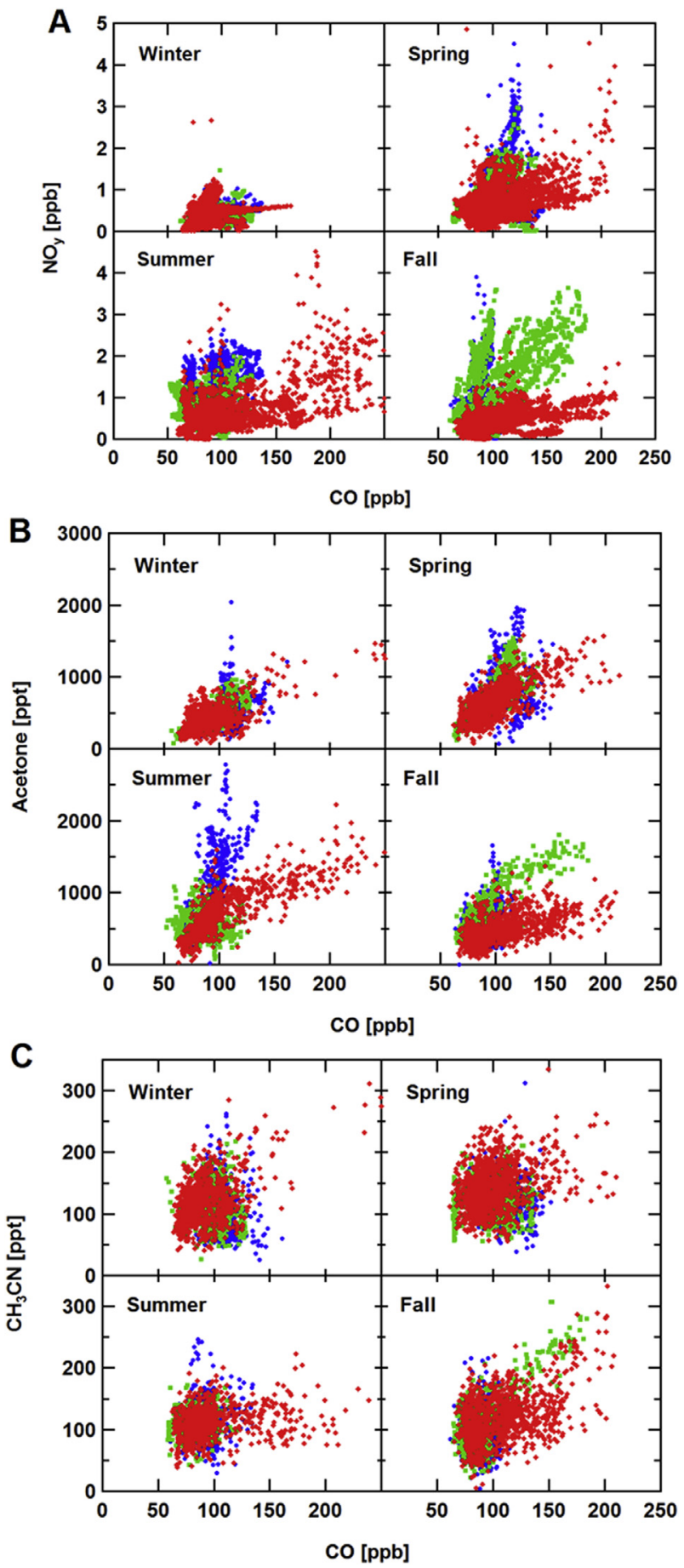

Fig. 5. Scatter plots of the seasonal relationships between $\mathrm{CO}$ and $\mathrm{A}) \mathrm{NO}_{y}, \mathrm{~B}$ ) acetone and C) $\mathrm{CH}_{3} \mathrm{CN}$. Different colors denote the different regions: Europe/West Asia (blue), Central Asia (green) and Southeast Asia (red). 
linear least squares fits are provided in Table 4 . We note that a number of factors other than differing source types, such as air mass age and level of dilution, can influence the observed ratios, causing them to differ from emission ratios, and here we use the observed, enhancement ratios to qualitatively understand possible sources rather than to definitively identify emission ratios. Additionally, the inclusion of all data points from each season means that many differing characteristics are represented (i.e. year, transport times, etc.), which lends itself to poor correlations and large scatter. However, there are also certain features which are dominant and pervasive during each season and we focus on these.

Relationships in winter are characterized by a lack of correlation with CO for all three tracers, with the exception of a small number of high values of acetone and acetonitrile, measured over Southeast Asia. This is an indication that the air sampled is primarily background air, which is not overly influenced by the boundary layer below, as stated previously. Strong convection is not typically observed in the winter months, making this an anticipated result.

During spring and summer we observed weak, positive correlations between $\mathrm{NO}_{y}$ and $\mathrm{CO}$ and stronger, positive correlations between acetone and $\mathrm{CO}$ over Southeast Asia. Acetone and $\mathrm{NO}_{y}$ remain uncorrelated with $\mathrm{CO}$ over Central Asia and Europe/West Asia, as does acetonitrile over all regions. Elevated acetone is primarily the result of increased photochemical production and biosphere emissions during spring and summer, however, these enhancements coupled with the many instances of increased $\mathrm{CO}$ point to increased input from the boundary layer via convection, particularly over Southeast Asia. $\mathrm{NO}_{y}$, while enhanced, is not as well correlated with $\mathrm{CO}$ as acetone and, while convective input is likely when elevated $\mathrm{NO}_{y}$ is coupled with elevated $\mathrm{CO}$, increased production of lightning $\mathrm{NO}_{x}$ is also likely. The lack of enhancement in acetonitrile in spring and its decrease in summer point to there being little to no input from biomass or biofuel burning.

Fall is the only season with a substantial number of measurements where acetonitrile was enhanced and correlated with $\mathrm{CO}$. Stronger correlations with $\mathrm{CO}$ were also observed for $\mathrm{NO}_{y}$ and acetone over all regions, and for acetonitrile measurements exhibiting enhancements also showed strong, positive correlations with $\mathrm{CO}$, and this is particularly strong over Central Asia. It is important to note that this branch includes data from 6 different flights, in different months and years, providing a strong indication that biomass burning emissions play a large role in trace gas composition in the UT over Central Asia during fall. In fact, the ratio observed for this branch, of $1.95 \mathrm{ppt}$ acetonitrile $\mathrm{ppb}^{-1} \mathrm{CO}$ is similar to other observations of biomass burning plumes originating in

Table 4

Slopes and correlation coefficients of trace gas relationships with CO.

\begin{tabular}{|c|c|c|c|c|c|c|c|}
\hline \multirow[t]{2}{*}{ Region } & \multirow[t]{2}{*}{ Season } & \multicolumn{2}{|c|}{$\begin{array}{l}\mathrm{NO}_{y} / \mathrm{CO} \\
(\mathrm{ppb} / \mathrm{ppb})\end{array}$} & \multicolumn{2}{|c|}{$\begin{array}{l}\text { Acetone/CO } \\
\text { (ppt/ppb) }\end{array}$} & \multicolumn{2}{|c|}{$\begin{array}{l}\mathrm{CH}_{3} \mathrm{CN} / \mathrm{CO} \\
\text { (ppt/ppb) }\end{array}$} \\
\hline & & $m$ & $R^{2}$ & $m$ & $R^{2}$ & $m$ & $R^{2}$ \\
\hline \multirow[t]{4}{*}{ Eastern Europe } & Winter & -0.0003 & 0.00 & 4.7 & 0.06 & -0.64 & 0.04 \\
\hline & Spring & 0.0101 & 0.04 & 4.9 & 0.04 & -0.27 & 0.02 \\
\hline & Summer & 0.0136 & 0.19 & 25.4 & 0.49 & 0.28 & 0.01 \\
\hline & Fall & 0.0022 & 0.00 & 3.4 & 0.03 & 0.01 & 0.00 \\
\hline \multirow[t]{4}{*}{ Central Asia } & Winter & -0.0007 & 0.00 & 8.2 & 0.34 & -0.44 & 0.03 \\
\hline & Spring & 0.0060 & 0.06 & 14.2 & 0.60 & 0.11 & 0.00 \\
\hline & Summer & -0.0017 & 0.01 & 13.6 & 0.42 & 0.21 & 0.02 \\
\hline & Fall & 0.0213 & 0.37 & 13.2 & 0.68 & 1.68 & 0.56 \\
\hline \multirow[t]{4}{*}{ East Asia } & Winter & 0.0040 & 0.06 & 5.3 & 0.63 & 1.08 & 0.56 \\
\hline & Spring & 0.0070 & 0.20 & 8.1 & 0.54 & 0.58 & 0.13 \\
\hline & Summer & 0.0660 & 0.25 & 7.3 & 0.68 & 0.20 & 0.06 \\
\hline & Fall & 0.0042 & 0.20 & 4.0 & 0.33 & 0.66 & 0.22 \\
\hline
\end{tabular}

Asia (Andreae and Merlet, 2001). Also observed were much higher levels of $\mathrm{NO}_{y}$ and acetone over Central Asia which were strongly correlated with $\mathrm{CO}$.

For the NMHCs the number of samples is insufficient to allow for estimates of enhancement ratios from correlation plots. Therefore, enhancement ratios were instead determined for individual samples using the equation

$\frac{\Delta X}{\Delta Y}=\frac{X_{\text {observed }}-X_{\text {background }}}{Y_{\text {observed }}-Y_{\text {background }}}$

where $X$ and $Y$ are the species of interest. The background values were determined from the mean concentrations of the samples for air masses having been the least influenced by pollution sources during each season. These were identified as those samples having the lowest $10 \%$ of CO concentrations as well as low mixing ratios of other trace gases. This method is similar to that used to determine background values for aircraft campaigns (Barletta et al., 2009; Blake et al., 2003).

Longitudinal profiles of the enhancement ratios $\Delta$ ethane $/ \Delta C O$ and $\Delta$ propane/ $\Delta$ benzene in all seasons are shown in Fig. 6 . Ethane $\left(\mathrm{C}_{2} \mathrm{H}_{6}\right)$ and $\mathrm{CO}$ are both relatively long-lived trace gases with comparable atmospheric lifetimes ( $>2$ months in the UT) which are controlled by reaction with the hydroxyl radical $(\mathrm{OH})$. Therefore their enhancement ratios are expected to be modified little from the emission ratios by atmospheric processing. Their ratio has been chosen to examine the relationship between alkanes and combustion products. To this end we also chose to compare propane and benzene, which often arise from different sources (e.g. unburned fossil fuels and combustion processes, respectively), but also have similar atmospheric lifetimes. The longitudinal plots of $\Delta$ ethane/ $\triangle C O$ show values which are much lower over Southeast Asia (east of $100^{\circ} \mathrm{E}$ ), where ratios are almost always below $20 \mathrm{ppt} /$ ppb, than over Central Asia and Europe/West Asia. Regional differences in $\Delta$ propane/ $\Delta$ benzene are even more pronounced, particularly the frequent occurrence of ratios in excess of $10 \mathrm{ppt} / \mathrm{ppt}$ over Central Asia. Conversely, ratios between 5 and 10 ppt/ppt are commonly observed over Europe/West Asia, while over Southeast Asia values rarely exceed $5 \mathrm{ppt} / \mathrm{ppt}$.

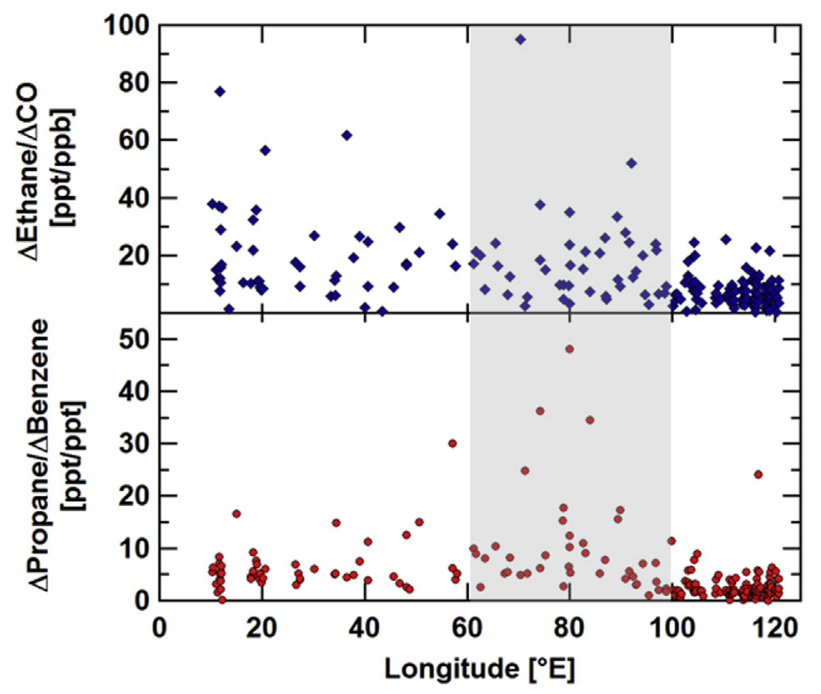

Fig. 6. NMHC enhancement ratios over Europe and Asia during CARIBIC flights to Guangzhou from Frankfurt, Germany. Gray shaded areas represent the Central Asian region $\left(60^{\circ} \mathrm{E}-100^{\circ} \mathrm{E}\right)$. 


\subsection{Case study: October 2006}

During the flights on 19-21 October 2006 the CARIBIC observatory encountered air masses with particularly strong enhancements in trace gases (Fig. 7). Following the general pattern observed along this route, higher $\mathrm{CO}$ concentrations were detected over Southeast Asia than over Europe or Central Asia, although there were also occasional periods of elevated levels of $\mathrm{CO}$ over Central Asia. Profiles of trace gases measured during this flight are shown in Fig. 8, along with additional NMHCs and perchloroethene $\left(\mathrm{C}_{2} \mathrm{Cl}_{4}\right)$. Ozone has been included, as periods with stratospheric influence are also included in this overview. Ethane and the butanes (i- \& n-butane; $\mathrm{C}_{4} \mathrm{H}_{10}$ ) serve as additional tracers of fossil fuel activity, while toluene has similar anthropogenic sources to benzene (combustion and solvent use) but a smaller biomass burning source. It also has a much shorter lifetime and can be used as a qualitative tracer of age. $\mathrm{C}_{2} \mathrm{Cl}_{4}$ is a man-made solvent and is a useful tracer for urban anthropogenic air masses.

Between $75^{\circ} \mathrm{E}$ and $100^{\circ} \mathrm{E}$ four whole air samples, labeled $1-4$ based on their location moving west to east, were collected, which had exceptionally high concentrations of NMHCs accompanied by only very slight elevations in CO (Fig. 8). As mentioned previously, this is not an uncommon observation in the UT over Central Asia, and this case study serves as a means to investigate the origins of these particular pollution events. In addition to elevated NMHCs, $\mathrm{NO}_{y}$ and $\mathrm{C}_{2} \mathrm{Cl}_{4}$ were enhanced during the collection periods for samples 2, 3 and 4 and acetonitrile was elevated during collection of samples 3 and 4 . These initial observations already point to different sources influencing the air masses encountered in the UT during this flight, with those to the east ( 3 and 4 ) having characteristics of both biomass burning and anthropogenic emissions (acetonitrile, $\mathrm{C}_{2} \mathrm{Cl}_{4}$, elevations in all NMHCs), and those to the west
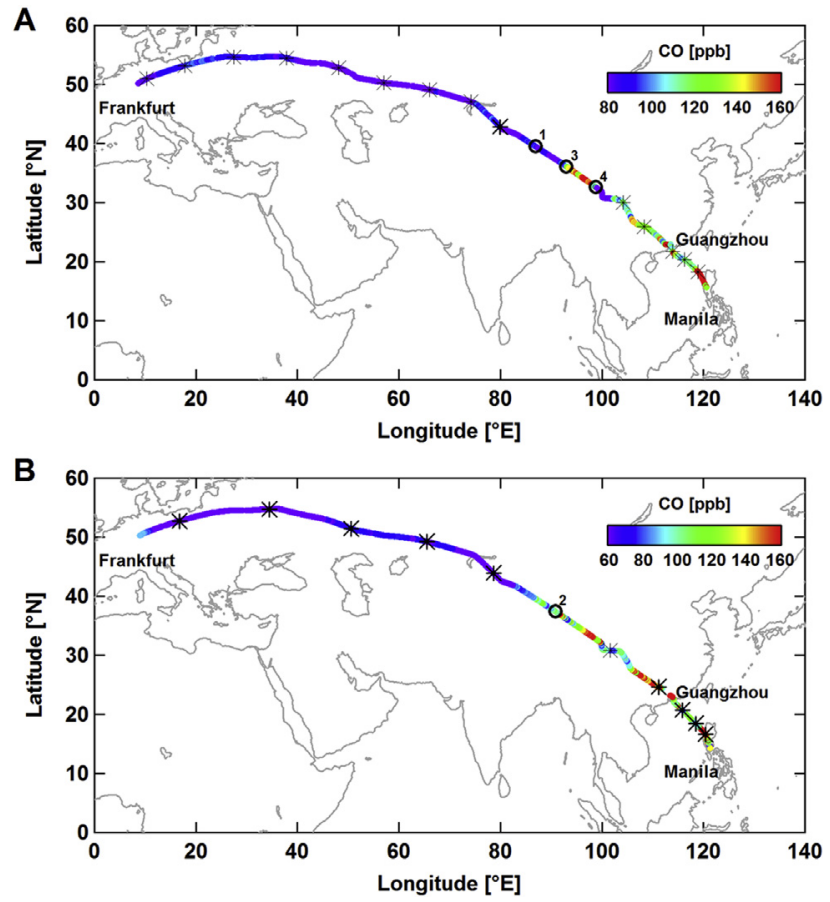

Fig. 7. Flight routes in October 2006 A) from Frankfurt to Manila and B) from Manila to Frankfurt. Routes are color coded for CO mixing ratio. Stars mark points where whole air samples were collected, open circles denote those whole air samples having elevated levels of NMHCs and halocarbons. (For interpretation of the references to colour in this figure legend, the reader is referred to the web version of this article.)
( 1 and 2 ) having stronger indications of fossil fuel-related emissions (elevated alkanes without elevated CO and acetonitrile).

Backward trajectory analysis in combination with IR satellite images (GOES-VISSR) and fire counts (MODIS) were used to investigate a potential influence of convection (Justice et al., 2002). Note that while the rapid vertical transport associated with convection is not captured by the meteorological analysis, colocation of trajectory position and convective cloud occurrence is a strong indicator for convective influence on the observations. Maximum pressures from the backward trajectories (Figs. 8 and 9, top panels) show that only sample 3 can be definitively connected to ascent from the boundary layer, with contact lower than $800 \mathrm{hPa}$ during the 5 days prior to measurement, pointing to encounter of the other trajectories with convective outflows as a means to explain these pollution events.

Given the spatial and temporal proximity of sample collection, the similarity of their trajectory data and also in their corresponding trace gas data, samples 1 and 2 are considered to be of similar origin and to have been collected within the same air mass. Both samples had enhancements in alkanes, particularly propane and the butanes, with only very small ( $10 \mathrm{ppb})$ enhancements in $\mathrm{CO}$ and no enhancement in acetonitrile. This points to emissions related to unburned fossil fuels, and is possibly related to fossil fuel extraction and processing. Backward trajectories show that air masses probed by samples 1 and 2 passed over western Asia and Europe at high altitude, and upward transport by local convection is supported by comparison of backward trajectory location with satellite images, which show persistent, vertically extended clouds on 19 October.

Trajectories for both samples 3 and 4 indicate that the air masses probed had passed over India, with the trajectory for sample 4 passing further south than sample 3. Between 17 and 20 October 2006 extensive fire activity was detected over northern India (Fig. 9b) while at the same time convective complexes were present over this region (Fig. 9c), and these were encountered by the trajectories for samples 3 and 4. Both samples have large enhancements in acetonitrile and some enhancement in $\mathrm{CO}$ as a result of encountering these biomass burning emissions, however, elevated $\mathrm{C}_{2} \mathrm{Cl}_{4}$ also indicates anthropogenic emissions, as does elevated toluene. Thus, these air masses appear to be influenced by a combination of biomass burning and urban anthropogenic emissions.

Similar results can be found when incidences of elevated alkanes are examined for other flights and are present in all seasons excepting summer. In general, elevated alkanes without concomitant elevations in other species which are traceable to Europe/West Asia (and to a lesser extent the Arabian Peninsula) tend to be encountered over the western part of Central Asia, while air masses originating in South Asian (Indian subcontinent) are most frequently encountered over the eastern part. Additionally, biomass burning signatures tend to be the strongest during fall, when fire activity is at its peak in India.

\section{Conclusions}

Analysis of CARIBIC data on flights between Frankfurt, Germany and Manila, the Philippines showed that three different regions with distinct pollution signatures can be identified, over Europe/ West Asia (between $10^{\circ} \mathrm{E}$ and $60^{\circ} \mathrm{E}$ ), Central Asia (between $60^{\circ} \mathrm{E}$ and $100^{\circ} \mathrm{E}$ ) and Southeast Asia (from $100^{\circ} \mathrm{E}$ to $125^{\circ} \mathrm{E}$ ). Investigation of trace gas composition and relationships between different species shows the influence of different source types and, by extension, source regions on the UT over Asia. In general, UT composition over Europe/West Asia was influenced by long range transport from North America and local convection, while over 

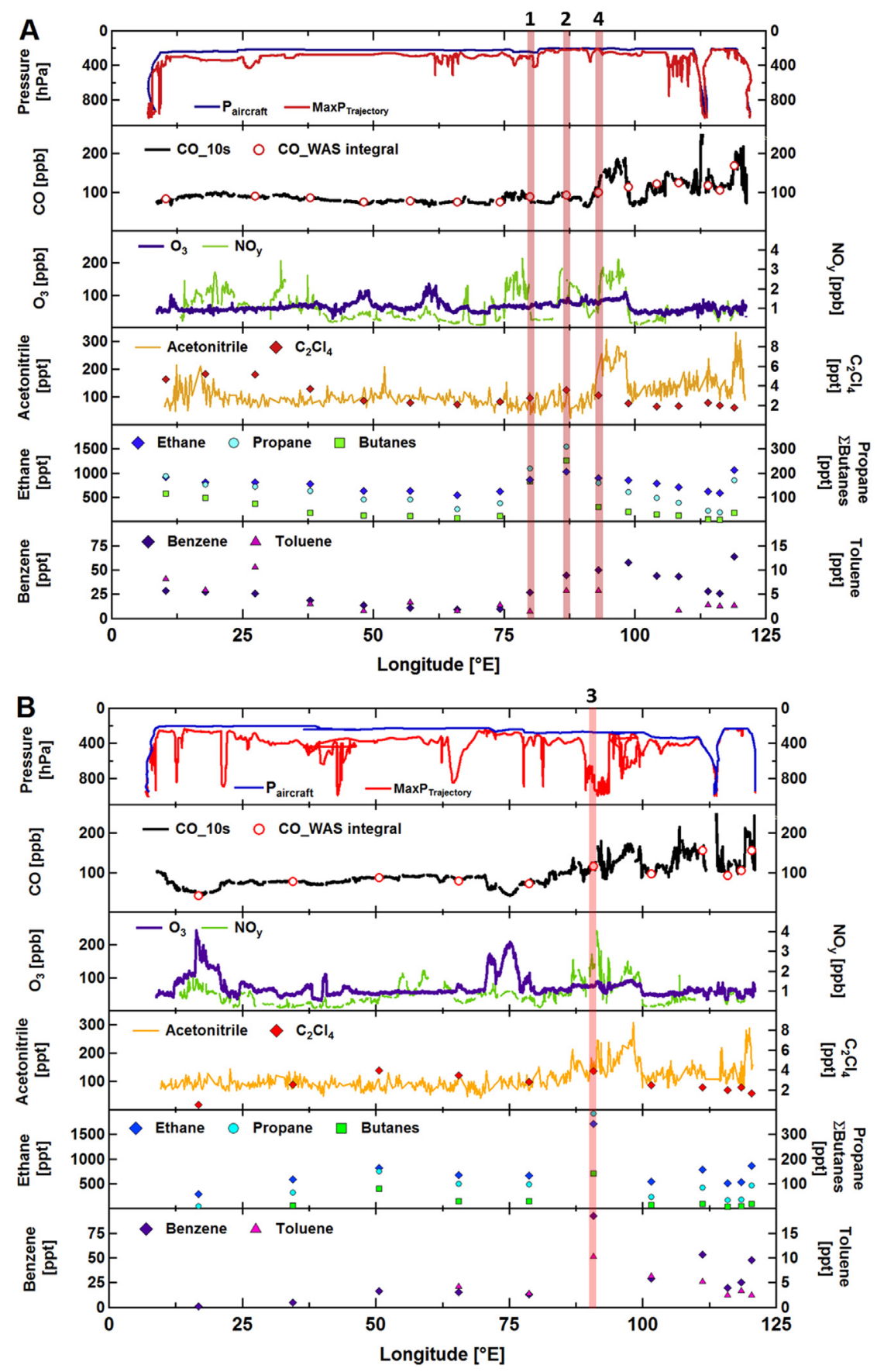

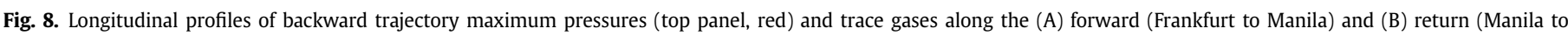

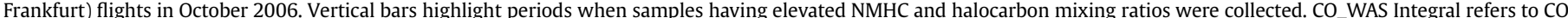

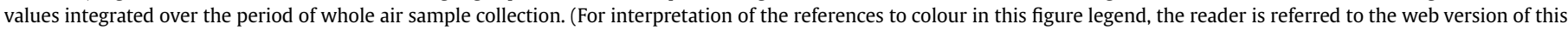
article.)

Southeast Asia the UT was influenced mainly by uplifted local and regional air masses which contained strong biomass burning signatures. The UT over Central Asia showed strong influence of convective vertical transport of regional pollution having signatures of a variety of sources.

On many CARIBIC flights noticeable enhancements in several trace gases above Central Asia were observed and used to identify different emission sources potentially responsible for the observed pollution patterns. In particular, the very high enhancements in alkanes along with low CO concentrations, regularly observed above Central Asia were a prominent feature of polluted air masses encountered along this route. A case study for October 2006 showed the complex interplay of different emissions and transport processes contributing to the observed tracer enhancements, and showed evidence of influence by both biomass/biofuel burning and urban emissions from South Asia and fossil fuel emissions from Europe/West Asia.

Findings from this study show the strong influence of both long range transport and convection on composition of the UT over Asia, and further indicate a strong and persistent connection between 

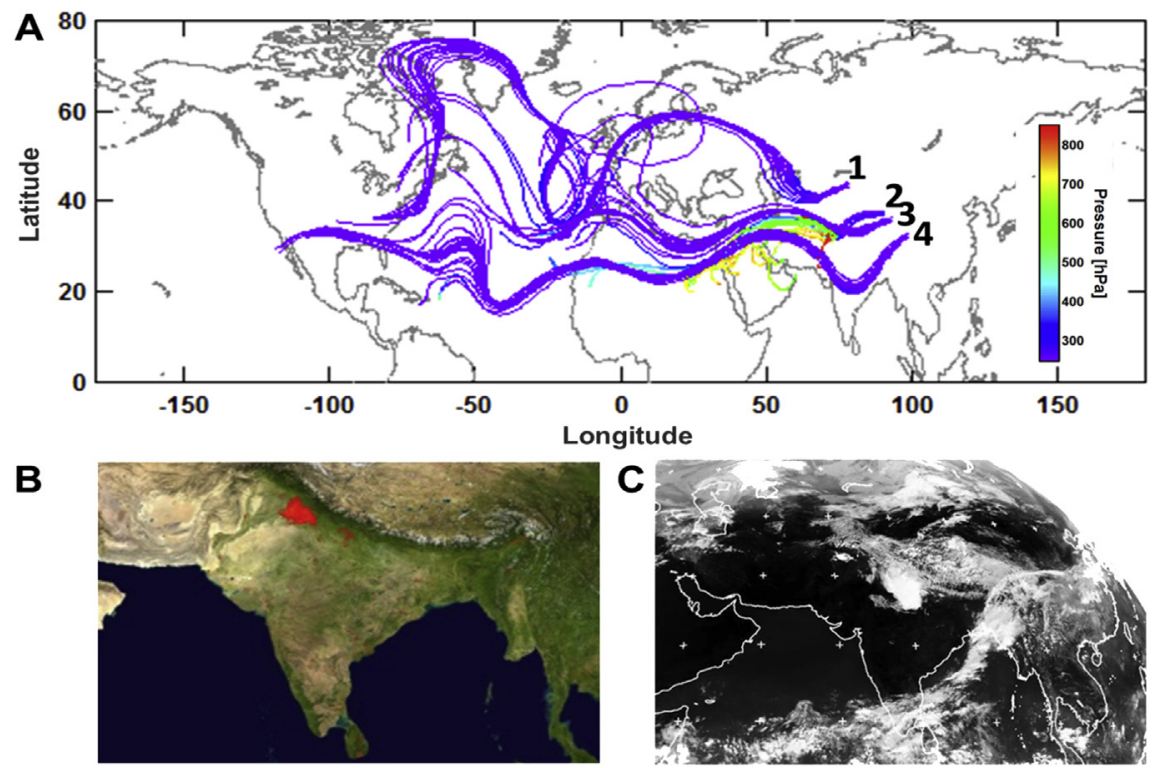

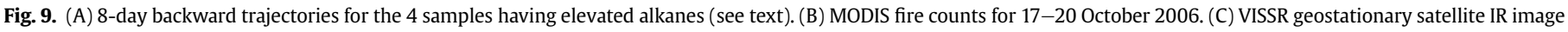

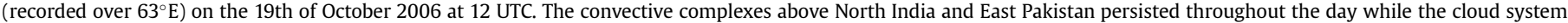
near the Aral Sea moved east over the course of the day.

regional (Europe/West Asia, Central and Southeast Asian) emissions and UT composition.

\section{Acknowledgements}

The authors would like to thank Lufthansa Airlines for their support of the CARIBIC observatory and Fraport for financial assistance. We also gratefully acknowledge the invaluable contributions of all members of the CARIBIC team, both in Mainz and at partner institutions. CARIBIC is part of IAGOS, and we acknowledge funding from the German Ministry of Education and Research (BMBF). S. Traud acknowledges support from the European Social Fund's Doctoral Studies and Internationalization Program DoRa.

\section{References}

Andreae, M.O., Merlet, P., 2001. Emission of trace gases and aerosols from biomass burning. Glob. Biogeochem. Cycles 15 (4), 955-966.

Auvray, M., Bey, I., 2005. Long-range transport to Europe: seasonal variations and implications for the European ozone budget. J. Geophys. Res. Atmos. 110 (D11), D11303. http://dx.doi.org/10.1029/2004JD005503.

Baker, A.K., Schuck, T.J., Slemr, F., van Velthoven, P., Zahn, A., Brenninkmeijer, C.A.M., 2011. Characterization of non-methane hydrocarbons in Asian summer monsoon outflow observed by the CARIBIC aircraft. Atmos. Chem. Phys. 11 (2), 503-518. http://dx.doi.org/10.5194/acp-11-503-2011.

Baker, A.K., Slemr, F., Brenninkmeijer, C.A.M., 2010. Analysis of non-methane hydrocarbons in air samples collected aboard the CARIBIC passenger aircraft Atmos. Meas. Tech. 3 (1), 311-321. http://dx.doi.org/10.5194/amt-3-311-2010.

Barletta, B., et al., 2009. Characterization of volatile organic compounds (VOCs) in Asian and north American pollution plumes during INTEX-B: identification of specific Chinese air mass tracers. Atmos. Chem. Phys. 9 (14), 5371-5388. http:// dx.doi.org/10.5194/acp-9-5371-2009.

Bergamaschi, P., Hein, R., Heimann, M., Crutzen, P.J., 2000. Inverse modeling of the global CO cycle 1 . Inversion of CO mixing ratios. J. Geophys. Res. Atmos. 105 (D2), 1909-1927.

Blake, et al., 2003. NMHCs and halocarbons in Asian continental outflow during the Transport and Chemical Evolution over the Pacific (TRACE-P) Field Campaign: comparison with PEM-West B. J. Geophys. Res. Atmos. 108 (D20), 8806. http:// dx.doi.org/10.1029/2002jd003367.

Blake, D.R., Rowland, F.S., 1995. Urban leakage of liquefied petroleum gas and its impact on Mexico City air quality. Science 269 (5226), 953-956. http:// dx.doi.org/10.1126/science.269.5226.953.

Brenninkmeijer, C.A.M., et al., 2007. Civil aircraft for the regular investigation of the atmosphere based on an instrumented container: the new CARIBIC system. Atmos. Chem. Phys. 7, 4953-4976.
Brough, N., et al., 2003. Intercomparison of aircraft instruments on board the C-130 and Falcon 20 over southern Germany during EXPORT 2000. Atmos. Chem. Phys. 3 (6), 2127-2138. http://dx.doi.org/10.5194/acp-3-2127-2003.

Cooper, O., Forster, C., Parrish, D., Trainer, M., Dunlea, E., Ryerson, T., Hübler, G., Fehsenfeld, F., Nicks, D., Holloway, J., 2004. A case study of transpacific warm conveyor belt transport: influence of merging airstreams on trace gas import to North America. J. Geophys. Res. Atmos. (1984-2012) 109 (D23).

de Gouw, J.A., Warneke, C., Parrish, D.D., Holloway, J.S., Trainer, M., Fehsenfeld, F.C., 2003. Emission sources and ocean uptake of acetonitrile $\left(\mathrm{CH}_{3} \mathrm{CN}\right)$ in the atmosphere. J. Geophys. Res. Atmos. 108 (D11), 4329. http://dx.doi.org/10.1029/ 2002JD002897.

Eckhardt, S., Stohl, A., Wernli, H., James, P., Forster, C., Spichtinger, N., 2004. A 15year climatology of warm conveyor belts. J. Clim. 17 (1), 218-237. http:// dx.doi.org/10.1175/1520-0442(2004)017<0218:AYCOWC>2.0.CO;2.

Heald, C.L., et al., 2003. Asian outflow and trans-Pacific transport of carbon monoxide and ozone pollution: an integrated satellite, aircraft, and model perspective. J. Geophys. Res. Atmos. 108 (D24), 4804. http://dx.doi.org/10.1029/ 2003jd003507.

Hoell, J.M., Davis, D.D., Liu, S.C., Newell, R., Shipham, M., Akimoto, H., McNeal, R.J., Bendura, R.J., Drewry, J.W., 1996. Pacific Exploratory Mission-West A (PEM-West A): September-October 1991. J. Geophys. Res. Atmos. 101 (D1), 1641-1653. http://dx.doi.org/10.1029/95JD00622.

Hoell, J.M., Davis, D.D., Liu, S.C., Newell, R.E., Akimoto, H., McNeal, R.J., Bendura, R.J., 1997. The Pacific exploratory mission-west phase B: February-March, 1994. J. Geophys. Res. Atmos. 102 (D23), 28223-28239. http://dx.doi.org/10.1029/ 97JD02581.

Jacob, D.J., Crawford, J.H., Kleb, M.M., Connors, V.S., Bendura, R.J., Raper, J.L., Sachse, G.W., Gille, J.C., Emmons, L., Heald, C.L., 2003. Transport and Chemical Evolution over the Pacific (TRACE-P) aircraft mission: design, execution, and first results. J. Geophys. Res. Atmos. 108 (D20), 9000. http://dx.doi.org/10.1029/ 2002JD003276.

Jacob, D.J., Field, B.D., Jin, E.M., Bey, I., Li, Q., Logan, J.A., Yantosca, R.M., Singh, H.B., 2002. Atmospheric budget of acetone. J. Geophys. Res. Atmos. 107 (D10) http:// dx.doi.org/10.1029/2001JD000694. ACH 5-1-ACH 5-17.

Justice, C.O., Giglio, L., Korontzi, S., Owens, J., Morisette, J.T., Roy, D., Descloitres, J., Alleaume, S., Petitcolin, F., Kaufman, Y., 2002. The MODIS fire products. Remote Sens. Environ. 83 (1-2), 244-262. http://dx.doi.org/10.1016/S0034-4257(02) 00076-7.

Krol, M.C., Lelieveld, J., Oram, D.E., Sturrock, G.A., Penkett, S.A., Brenninkmeijer, C.A.M., Gros, V., Williams, J., Scheeren, H.A., 2003. Continuing emissions of methyl chloroform from Europe. Nature 421, 131-135.

Kurokawa, J., Ohara, T., Morikawa, T., Hanayama, S., Janssens-Maenhout, G., Fukui, T., Kawashima, K., Akimoto, H., 2013. Emissions of air pollutants and greenhouse gases over Asian regions during 2000-2008: regional Emission inventory in ASia (REAS) version 2. Atmos. Chem. Phys. 13 (21), 11019-11058. http:// dx.doi.org/10.5194/acp-13-11019-2013.

Lai, S.C., Baker, A.K., Schuck, T.J., Slemr, F., Brenninkmeijer, C.A.M., van Velthoven, P. Oram, D.E., Zahn, A., Ziereis, H., 2011. Characterization and source regions of 51 high-CO events observed during Civil Aircraft for the Regular Investigation of the Atmosphere Based on an Instrument Container (CARIBIC) flights between 
south China and the Philippines, 2005-2008. J. Geophys. Res. Atmos. 116 (D20), D20308. http://dx.doi.org/10.1029/2011jd016375.

Lai, S.C., et al., 2010. Pollution events observed during CARIBIC flights in the upper troposphere between South China and the Philippines. Atmos. Chem. Phys. 10 (4), 1649-1660. http://dx.doi.org/10.5194/acp-10-1649-2010.

Lelieveld, J., et al., 2002. Global air pollution crossroads over the Mediterranean. Science 298 (5594), 794-799. http://dx.doi.org/10.1126/science.1075457.

Lewis, A.C., et al., 2013. The influence of biomass burning on the global distribution of selected non-methane organic compounds. Atmos. Chem. Phys. 13 (2), 851-867. http://dx.doi.org/10.5194/acp-13-851-2013.

Liu, H., Jacob, D.J., Bey, I., Yantosca, R.M., Duncan, B.N., Sachse, G.W., 2003. Transport pathways for Asian pollution outflow over the Pacific: interannual and seasonal variations. J. Geophys. Res. Atmos. 108 (D20), 8786. http://dx.doi.org/10.1029/ 2002JD003102.

Logan, J.A., 1983. Nitrogen oxides in the troposphere: global and regional budgets. J. Geophys. Res. Oceans 88 (C15), 10785-10807. http://dx.doi.org/10.1029/ JC088iC15p10785.

Mauzerall, D.L., Logan, J.A., Jacob, D.J., Anderson, B.E., Blake, D.R., Bradshaw, J.D., Heikes, B., Sachse, G.W., Singh, H., Talbot, B., 1998. Photochemistry in biomass burning plumes and implications for tropospheric ozone over the tropical South Atlantic (vol. 103, pg 8401, 1998). J. Geophys. Res. Atmos. 103 (D15), 19281-19282.

Nara, H., Tanimoto, H., Nojiri, Y., Mukai, H., Zeng, J., Tohjima, Y., Machida, T., 2011. CO emissions from biomass burning in South-east Asia in the 2006 El Niño year: shipboard and AIRS satellite observations. Environ. Chem. 8 (2), 213-223. http://dx.doi.org/10.1071/EN10113.

Nedelec, P., Thouret, V., Brioude, J., Sauvage, B., Cammas, J.P., Stohl, A., 2005. Extreme CO concentrations in the upper troposphere over northeast Asia in June 2003 from the in situ MOZAIC aircraft data. Geophys. Res. Lett. 32 (14), L14807. http://dx.doi.org/10.1029/2005gl023141.

Novelli, P.C., 1999. CO in the atmosphere: measurement techniques and related issues. Chemosphere Glob. Change Sci. 1 (1-3), 115-126. http://dx.doi.org/ 10.1016/s1465-9972(99)00013-6.

Novelli, P.C., Steele, L.P., Tans, P.P., 1992. Mixing ratios of carbon monoxide in the troposphere. J. Geophys. Res. Atmos. 97 (D18), 20731-20750. http://dx.doi.org/ 10.1029/92jd02010.

Ohara, T., Akimoto, H., Kurokawa, J., Horii, N., Yamaji, K., Yan, X., Hayasaka, T., 2007. An Asian emission inventory of anthropogenic emission sources for the period 1980-2020. Atmos. Chem. Phys. 7 (16), 4419-4444. http://dx.doi.org/10.5194/ acp-7-4419-2007.

Park, M., Randel, W.J., Emmons, L.K., Livesey, N.J., 2009. Transport pathways of carbon monoxide in the Asian summer monsoon diagnosed from Model of Ozone and Related Tracers (MOZART). J. Geophys. Res. Atmos. 114 http:// dx.doi.org/10.1029/2008jd010621.

Qian, W., Lee, D.-K., 2000. Seasonal march of Asian summer monsoon. Int. J. Climatol. 20 (11), 1371-1386. http://dx.doi.org/10.1002/1097-0088(200009)20: $11<1371$ ::aid-joc538>3.0.co;2-v.

Randel, W.J., Park, M., Emmons, L., Kinnison, D., Bernath, P., Walker, K.A., Boone, C., Pumphrey, H., 2010. Asian monsoon transport of pollution to the stratosphere. Science 328 (5978), 611-613. http://dx.doi.org/10.1126/science.1182274.

Scharffe, D., Slemr, F., Brenninkmeijer, C.A.M., Zahn, A., 2012. Carbon monoxide measurements onboard the CARIBIC passenger aircraft using UV resonance fluorescence. Atmos. Meas. Tech. 5 (7), 1753-1760. http://dx.doi.org/10.5194/ amt-5-1753-2012.

Scheele, M.P., Siegmund, P.C., Van Velthoven, P.F.J., 1996. Sensitivity of trajectories to data resolution and its dependence on the starting point: in or outside a tropopause fold. Meteorol. Appl. 3 (3), 267-273. http://dx.doi.org/10.1002/ met.5060030308.
Scheeren, H.A., et al., 2003. The impact of monsoon outflow from India and Southeast Asia in the upper troposphere over the eastern Mediterranean. Atmos. Chem. Phys. 3 (5), 1589-1608. http://dx.doi.org/10.5194/acp-3-15892003.

Schuck, T.J., Brenninkmeijer, C.A.M., Baker, A.K., Slemr, F., von Velthoven, P.F.J. Zahn, A., 2010. Greenhouse gas relationships in the Indian summer monsoon plume measured by the CARIBIC passenger aircraft. Atmos. Chem. Phys. 10 (8), 3965-3984. http://dx.doi.org/10.5194/acp-10-3965-2010.

Schuck, T.J., Brenninkmeijer, C.A.M., Slemr, F., Xueref-Remy, I., Zahn, A., 2009 Greenhouse gas analysis of air samples collected onboard the CARIBIC passenger aircraft. Atmos. Meas. Tech. 2 (2), 449-464. http://dx.doi.org/10.5194| amt-2-449-2009.

Singh, H.B., Brune, W.H., Crawford, J.H., Flocke, F., Jacob, D.J., 2009. Chemistry and transport of pollution over the Gulf of Mexico and the Pacific: spring 2006 INTEX-B campaign overview and first results. Atmos. Chem. Phys. 9 (7), 2301-2318. http://dx.doi.org/10.5194/acp-9-2301-2009.

Singh, H.B., Kanakidou, M., Crutzen, P.J., Jacob, D.J., 1995. High-concentrations and photochemical fate of oxygenated hydrocarbons in the global troposphere. Nature 378 (6552), 50-54.

Sprung, D., Zahn, A., 2010. Acetone in the upper troposphere/lowermost stratosphere measured by the CARIBIC passenger aircraft: distribution, seasonal cycle, and variability. J. Geophys. Res. Atmos. 115 (D16), D16301. http://dx.doi.org/ 10.1029/2009JD012099.

Streets, D.G., et al., 2003. An inventory of gaseous and primary aerosol emissions in Asia in the year 2000. J. Geophys. Res. Atmos. 108 (D21), 8809. http://dx.doi.org/ 10.1029/2002jd003093.

Tanimoto, H., et al., 2008. Diagnosing recent $\mathrm{CO}$ emissions and ozone evolution in East Asia using coordinated surface observations, adjoint inverse modeling, and MOPITT satellite data. Atmos. Chem. Phys. 8 (14), 3867-3880. http://dx.doi.org/ 10.5194/acp-8-3867-2008.

Turquety, S., et al., 2008. CO emission and export from Asia: an analysis combining complementary satellite measurements (MOPITT, SCIAMACHY and ACE-FTS) with global modeling. Atmos. Chem. Phys. 8 (17), 5187-5204. http:/ dx.doi.org/10.5194/acp-8-5187-2008.

van Velthoven, P., 2014. Meteorological Analysis of CARIBIC by KNMI. http://www. knmi.nl/samenw/campaignsupport/CARIBIC/\#LH.

Wernli, H., Davies, H.C., 1997. A Lagrangian-based analysis of extratropical cyclones I: the method and some applications. Q. J. R. Meteorol. Soc. 123 (538), 467-489. http://dx.doi.org/10.1002/qj.49712353811.

Woo, J.H., et al., 2003. Contribution of biomass and biofuel emissions to trace gas distributions in Asia during the TRACE-P experiment. J. Geophys. Res. Atmos. 108 (D21), 8812. http://dx.doi.org/10.1029/2002jd003200.

Zahn, A., Brenninkmeijer, C.A.M., Asman, W.A.H., Crutzen, P.J., Heinrich, G., Fischer, H., Cuijpers, J.W.M., van Velthoven, P.F.J., 2002. Budgets of $\mathrm{O}_{3}$ and $\mathrm{CO}$ in the upper troposphere: CARIBIC passenger aircraft results 1997-2001. J. Geophys. Res. Atmos. 107 (D17), 4337. http://dx.doi.org/10.1029/ 2001JD001529.

Zahn, A., Brenninkmeijer, C.A.M., van Velthoven, P.F.J., 2004. Passenger aircraft project CARIBIC 1997-2002, Part I: the extratropical chemical tropopause. Atmos. Chem. Phys. Discuss. 4 (1), 1091-1117. http://dx.doi.org/10.5194/acpd-41091-2004.

Zhang, Q., et al., 2009. Asian emissions in 2006 for the NASA INTEX-B mission. Atmos. Chem. Phys. 9 (14), 5131-5153. http://dx.doi.org/10.5194/acp-9-51312009.

Ziereis, H., Schlager, H., Schulte, P., van Velthoven, P.F.J., Slemr, F., 2000. Distributions of $\mathrm{NO}, \mathrm{NO}_{x}$, and $\mathrm{NO}_{y}$ in the upper troposphere and lower stratosphere between $28^{\circ}$ and $61^{\circ} \mathrm{N}$ during POLINAT 2. J. Geophys. Res. Atmos. 105 (D3), 3653-3664. http://dx.doi.org/10.1029/1999JD900870. 